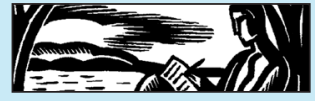

\title{
Beyond the Subject - Towards the Object? Nancy K. Miller's What They Saved: Pieces of a Jewish Past (2011) and the Materiality of Life Writing
}

\author{
Anne Rüggemeier \\ University of Heidelberg
}

\section{ABSTRACT}

In contrast to a long scholarly tradition that "separated subject from object, mind from matter" (Hodder 2012, p. 15), current writers of autobiography no longer ignore the fact that "the content of our so-called inner lives comes heavily freighted with material from outer sources" (Eakin 2009, p. 102). The focus on things runs counter to internal and essential concepts of selfhood as they are rooted in Western thinking and rather make visible the material world, the body and the environment as formative factors of selfhood. It thereby contrasts the Cartesian concept of self founded on thought and reflection with a concept of self based on materiality. Drawing on Nancy K. Miller's autobiography What They Saved: Pieces of a Jewish Past (2011) this paper will demonstrate that autobiographical objects foster a relational concept of self that is situated in the in-betweenness of subject and object, ego and autre as well as between the biographical and the autobiographical. Thus, the integration of objects highlights the fact that existence is not an individual affair, but that an autobiographical self emerges through and as part of his/her entangledness. Connected to this is the observation that objects function as a form of resistance against the processes of mind based epistemology and make a plea for "situated knowledges" (Haraway 1988). Finally, the essay takes a glimpse at some contemporary autobiographies from Britain, Germany and Sweden to illustrate that object based life writing and the specific epistemology connected to it are worthy of further investigation. 


\section{ABSTRACT IN GERMAN}

Entgegen einer geistesgeschichtlichen Tradition, in der sowohl Subjekt und Objekt als auch Geist und Dinglichkeit als separat voneinander gedacht wurden, artikulieren viele auto/biographische Texte der Gegenwart die bedeutende Rolle, die Dingen und Artefakten für die Konstituierung des autobiographischen Subjekts zukommt. Im Kontrast zu den klassischen, auf Innerlichkeit konzentrierten, cartesianischen Selbstkonzepten, wie sie innerhalb der westlichen Autobiographietheorie eine lange Tradition besitzen, wird in gegenwärtigen auto/biographischen Diskursen vermehrt ein Selbstkonzept verhandelt, das den Körper, die materielle Umwelt und Dinge als formative Faktoren des Selbst ergründet. Am Beispiel von Nancy K. Millers Auto/biographie What They Saved: Pieces of a Jewish Past (2011) untersucht der folgende Beitrag, inwieweit autobiographische Objekte einem relationalen Identitätsverständnis Vorschub leisten, welches in dem Zwischenraum von Subjekt und Objekt, von ich und anderem als auch zwischen dem biographischen und dem autobiographischen Interesse angesiedelt ist. Die Konzentration auf materielle Artefakte dient in diesem Zusammenhang der Erkenntnis, dass das autobiographische Selbst sich in der Verstrickung und Beziehungshaftigkeit mit den anderen, und den kulturellen Objektivationen der es umgebenden Dingwelt, entwickelt. Die auto/biographischen Dinge zeigen insofern die Defizite einer rein geistig fundierten Erkenntnistheorie auf und plädieren demgegenüber für die situative Bedingtheit des (autobiographischen) Wissens. Ein Blick in die europäische Autobiographie der Gegenwart rundet die Argumentation ab.

Keywords: family biography, auto/biographical objects, relationality, postmemory, situated knowledges, entanglements

\section{INTRODUCTION: LIFE WRITING AS A STORY ABOUT THINGS? OR "HOW I FOUND MY FAMILY IN A DRAWER"}

"The material world surrounds us and shapes us, and yet, in many ways, we have barely begun to study its role in our live" (Boivin 2008, p. 225). According to the archeologist Nicole Boivin Western ideological culture is deeply rooted in idealism, which, in the tradition of Plato, regarded things as mere projections of concepts and ideas. As a consequence, things have long been regarded as a mere symbolic system not regarding the fact that the material world "evoke[s] experiences that lie beyond the verbal, beyond the conceptual, and beyond even the conscious" (Boivin 2008, p. 8). Taking Nancy K. Miller's auto/biography What They Saved: Pieces of a Jewish Past (2011) as an example, this paper argues that the material world, long neglected in autobiography studies, has finally caught 
up with the master narrative of the cogito. In this book, Miller tells the story of a daughter who inherits a family history that is not transmitted via narration, but via a range of objects. This is the beginning of a decade long quest in which Miller not only reconstructs the biography of her late father and interrelates it with her own autobiography but, additionally, produces something like a biography of objects. However, unlike narrative, the objects continuously provoke an awareness for the unknowable; they refuse to surrender to the mechanisms of personal sense-making strategies. The autobiographical I soon has to accept that they constitute a "treasure of possible knowledge, inherited but never fully known" (p. 70). This piece of life writing hints at the fact that objects in autobiographical discourse represent epistemology's other: they turn the focus on the things that cannot be known, the stuff that resists (narrative) sense making.

Like many of those texts written by so-called "autobiographical children" (Porter 2011, p. 2) during the last two decades, also Nancy K. Miller's auto/biography What They Saved begins with the death of a parent, in this case the father. ${ }^{1}$ Nancy, Miller's autobiographical protagonist, takes this as a reason to try to come to terms with her family's past. Thus, What They Saved combines two narrative strands: on the one hand, it tells the story of a family - the father's side of the branch, the Kipnises from Kishinev/Moldavia, who immigrated to the United States in 1904, fleeing from the pogroms against Jewish People at the beginning of the $20^{\text {th }}$ century - and on the other hand, it focuses on the daughter's story and her search for roots.

When my father died, I became a middle-aged Jewish orphan. It's not that I wasn't already Jewish, of course, or that I set out to say Kaddish for him - I had no idea how to do that, even if it had been a daughter's place. But now that the last keeper of my Jewish past was dead and I was free to put it behind me, I started worrying about the future of my Jewish self. (p. 3)

Though Nancy has hitherto been happy to leave her Jewish roots behind, she suddenly becomes aware of the fact that she lost the last connection to a family history that has not been transmitted to her but still constitutes a part of her identity.

Fortunately, she inherits her father's drawer which contains an amalgam of mysterious objects like unidentified locks of hair in a French soap box, an embroidered tallis bag with tefillin, ${ }^{2}$ a cigarette case, a postcard from Argentina, a cemetery receipt and letters written in Yiddish. As she slowly pieces together her "family biography" (p. 150), she gets increasingly connected to an immigrant narrative that began in Eastern Europe at the turn of the twentieth century, when her ancestors headed for the 
Lower East Side of Manhattan. Though the text can be called an autobiography, it kind of marginalizes the 'autobiographical I' as protagonist to concentrate on the biographies of the other family members, most of whom have never been known by the 'autobiographical I.' In other words, Miller's text invents a shift from 'I' to 'they' and thereby also implies a shift in the sources of the autobiographical text which does not rely on personal memories but rather on a range of material and detective work. As the autobiographer's story is closely linked with her attempt to unravel the meaning and the contexts of the heirlooms, she is not only writing an auto/biography of self and family, but also a biography of objects.

Miller's endeavor to articulate the silent and to re-contextualize the fragmentary results in a decade-long quest. One attempt to contextualize the objects is by travel. The family biographer visits long forgotten relatives in other parts of the States, establishes ties with the Argentinian branch of the family, visits forgotten family plots in Israel and embarks on a root trip ${ }^{3}$ to Moldavia.

In the absence of stories passed down, of ties maintained, of documents preserved, I've embarked on a project of rerooting, rerouting, reimagining this family that until recently was almost entirely lost to me. Re-creating this family, however, is not an attempt to establish bonds where none existed. It's more a matter of putting these tiny shots of information, these bits of archival DNA, into the history of which they were excised through silence, and imagining what might have happened if they had been put into words. (p. 63)

As the phrase "archival DNA" foregrounds, the autobiographer develops an awareness for the fact that her life story is not limited by the events between her birth and her death, but that there exists a dimension of her own history about which she had been largely unaware.

\section{POSTMEMORY, THE NARRATIVE UNCONSCIOUS AND DEEP IDENTITY}

Although the inherited artefacts function as transitional objects because they bridge the generational distance between the family's Eastern European past and the younger generation, they simultaneously highlight the fact that Nancy lacks the transgenerational dimension of memory which Marianne Hirsch has compellingly described as postmemory (cf. Hirsch 1997). Miller's autobiographer has been excluded from the community of remembrance and therefore does not know the family stories in which to situate/position the objects. The objects cannot function as 
triggers of certain memories as the family biographer has been excluded from the frames of knowledge necessary to interpret the objects. This is why the objects cannot serve as triggers of postmemory, but rather point towards the interpretative gaps resulting from the third generation's excludedness from the family history of the Kipnises. The objects cannot build connections between "first-and-second generation remembrance, memory and postmemory" (Hirsch 1997, p. 23) because the stories and events to which the objects allude have not been transferred to the autobiographer. Consequently, Nancy's search for solid answers repeatedly results in epistemological blind alleys ("The answer belongs to one of the many stories that were never passed on"; p. 43).

Mark Freeman described this kind of "underground history" (Freeman 2010, p. 102) to one's own life story as the narrative unconscious:

\footnotetext{
With this phrase, I refer not to that more private, secretive dimension of the unconscious posited by psychoanalysis but to the cultural dimension specifically, to those culturally rooted aspects of one's history that remain uncharted and that, consequently, have yet to be incorporated into one's story. [...] Insofar as the narrative unconscious is operative in one's history, there exists the need to move beyond personal life in telling one's own story, into the shared life of culture. (Freeman 2010, p. 96f.)
}

The inherited objects are like an anchor into the past that connects the auto/biographer with her family's Jewishness. The artifacts were sensorially present during past moments (prayer) and events (bar mitzvah, wedding, pogroms). Nevertheless, they are only signs or traces: they represent deep strata of her family history and therefore also of her own story of which she is largely, if not entirely unaware. They point towards her "deep identity," which Freeman defines as "those dimensions of identity that find their origin not in the personal particulars of a life but in the fabric of history" (Freeman 2010, p. 122) and which rouse an awareness for the fact that autobiography is not exclusively a matter of representing a life from birth until death but also of discerning what Miller calls the "mute history" (p. 4), the untold and unwritten stories, personal as well as cultural, that are in important respects constitutive of her autobiographical self: "This family, over generations, had no doubt left discernible traces - in objects, in documents and finally in me. I could feel that mute history like a deposit in my body [...]" (ibid.). As the paradoxical combination of the adjectives "discernible" and "mute" highlights, Miller's identity narrative is written in the oscillating space between what can be found out and what is forever lost. As a consequence, the concept of self knowledge or the idea of self-transparency is shown to be highly contingent as a great part of the 
knowledge that is important to understand one's own autobiography is inaccessible for the self.

The heirlooms serve as fragments or "stubborn survivors" (Hirsch 1997, p. 13) of a disappeared world. Although the objects cannot be regarded as pieces of evidence for any searched for truth or "real past," they nevertheless function as perspectival filters through which the scope of possible stories about the past can be imagined. Miller's object-based auto/biographical epistemology highlights the tension between the knowable and the unknown, stories that might be recovered and those which are lost forever. Her narrative is not based on memory but on a quest.

\section{MUTE OBJEGTS AS PLACEHOLDERS FOR “THE PRESENCE OF WHAT IS MISSING"}

As the subtitle already has it, Miller's protagonist cannot hope for a coherent story of her familial past, but has to be satisfied with Pieces of a Jewish Past. Nancy is confronted with fragmentary material ("a clutch of loose images, without date or identification" (p. 32) and her writing practice consists in bridging fragments often without being able to fill in the spaces in between: "Trying to connect the dots, to fill in the blank spaces of the great unknown canvas of my lost family" (p. 34). Thus, the heirlooms represent a specific epistemological gap ("The collection, however eclectic, pointed to a specific enough elsewhere, a map of meaning and relations that nonetheless eluded me"; p. 4). Next to the things found out there is a constant awareness of those things that are lost or destroyed. Put differently, the text evokes a constant awareness that next to What They Saved there exists a wide range of material which they did not save. Maria Tamboukou makes a similar observation regarding biographical work based on archival findings: "[I]n the same way that we interpret voices, we should perhaps start interpreting silences or somehow include them in our analysis" (2013, p. 3). The single isolated objects found in the drawer point to the millions of other things that are lost and remind the reader that Nancy's collection is actually full of absences, of fragments and of discontinuities. As an auto/biography based on things What They Saved highlights the significance of absence, which becomes visible as "the presence of what is missing" (Freeman 2010, p. 100). Whatever is there exists in relation to what is not.

Nevertheless, though her father's silence cut Nancy off from the threads of memory that could connect her to the familial past, the objects found in the drawer make it possible to re-enter the familial past through the back-door: “[M]y father's tendency to hoard outwitted his failure to tell 
his family's story" (p. 70). Her late father was not a teller, but a collector of the Kipnis's past. This is why, despite his silence, Nancy's father has finally transmitted the family story to the next generation. However, not as a knowable and coherent story, but rather as a "treasure of possible knowledge, inherited but never fully known, collected, and stored in a drawer full of abandoned memories" (p. 70). While giving insight into her family research as a most objectified and scientific undertaking involving lots of experts like genealogists and archivists, Miller still unsettles her readers' expectations for a 'true' story by hinting at the limits of knowledge: "Still, what choice did I have but to rely on the unreliable" (p. 182). Thus, the specific narrative circumstances of What They Saved provoke the reader to interchange (the expectation of) truth with imagination and the search for the factual with a consciousness for the possible.

The inherited artefacts point towards the dependency on context and the important role of communities of remembrance as has also been stated by Joanne Karpinski: "The auto/biographical function of artefacts, then, is highly contingent on context. Cut off from the communities that create and preserve them, such artefacts may be rendered illegible [...]" (2001, p. 56). Actually, Miller's protagonist does gain important knowledge which places her in a new cultural, religious and symbolic context and this enables her to fill up some of the previous gaps. Nevertheless, even though the family biographer sometimes manages to re-contextualise the objects in different times and circumstances, she is continually confronted with the limits of re-construction and the realm of the unknowable.

As a consequence, Miller's autobiographical project is specifically shaped by an awareness for mnemonic gaps. By introducing the objects as starting points of her search, the author specifically points towards moments of absence, feelings of loss and the limits of reconstructable knowledge. By demonstrating that the meaning of the objects cannot be derived from the found artefacts alone, but only by situating them in specific (cultural, familial or even religious) frames of knowledge, it becomes clear that neither things nor people can be grasped in isolation but need to be contextualized.

\section{"DAS FREMDE IM EIGENEN" OR BEYOND THE (KNOWN) SUBJECT}

While traditional autobiography celebrated the Cartesian Cogito, the knowing subject, that is able to order its life story through a sensemaking narrative, the integration of objects provokes an awareness for the unknowable, the refusal to surrender to the mechanisms of personal 
sense-making strategies. The strangeness and obscurity of the inherited artefacts, which elude the searched for knowledge, provoke a reconsideration of the unknown and alien elements in one's own self. It is this unknown part which the German literary scholar Dorothee Kimmich has termed as "das Fremde im Eigenen" (Kimmich 2011, p. 33).

It is especially through the practice of travel in a country whose language and culture is beyond understanding for the autobiographical protagonist, that Nancy perceives her known self as different and unknown. For the Moldavian population she simply represents an "Amerikanka looking for her babushka" (p. 161) or, put differently, one of the many Americans on a family root trip. Far away from her usual context, the biographer feels vulnerable. She is dependent on others who know the language and the routes to the places she is looking for. This experience of dependency opens up unknown or at least less known parts of her own self to the analytic American scholar and self-conscious feminist critic. She feels frustrated, because she has not found what she has been looking for. She feels betrayed by her guide Slava and is angry at herself because she has not brought enough cash to this place that doesn't accept credit cards. And suddenly she is overwhelmed by tears:

And before I know it, I'm sobbing in the empty restaurant. I cannot stop weeping. [...] The whole trip is suddenly concentrated in this moment of humiliation. Who am I, the woman weeping in Tulchin? What am I weeping about? It was a mistake to go alone. [...] The truth is, I didn't have the right person to go with. More tears about that. (p. 173)

Left in unknown circumstances, the known self gradually withdraws to clear the path for the self's unknown other that looms large in the background. The autobiographer experiences herself as a different woman in another context. This highlights the fact that subjects are intimately produced by the environments they inhabit. Against a scholarly tradition that regarded humans mainly as minds, the episode in Tulchin demonstrates the impact of the political, economic, social, cultural and geographic context. The self is not an inert system and self-knowledge can only be conceptualized as embodied and situated knowledge. The new cultural context makes Miller's autobiographical protagonist insecure. However, the experience of vulnerability also connects her to new aspects of her own self. Thus, claims of knowledge, even those about self-knowledge, cannot be grasped as unlocated. The insistence on context, or rather location, resists the politics of closure and features instability or even "vulnerability" (Haraway 1988, p. 590) instead.

This doubt about self-presence or the possibility of self-knowledge (transparency of the self to the self) has been diagnosed as the "death of 
the subject.' Alas, Donna Haraway argues that even though "the boys in the human sciences have called this doubt about self-presence the "death of the subject"' (p. 585), it is rather a specific concept of the subject as a single ordering point of will and consciousness that might be considered dead. According to Haraway, the idea of the master subject has to be interchanged with the split and contradictory self: "Subjectivity is multidimensional [...]. The knowing self is partial in all its guises, never whole, simply there and original" (p. 586). And she goes on to explain that it is exactly the insight that subjectivity is multidimensional and not a single ordering point that allows for real dialogue and "shared conversations in epistemology" (p. 584) to happen.

\section{THE VERY MATERIALITY OF HUMAN LIFE - 'THINGNESS' AS A CLUE TO AUTO/BIOGRAPHICAL IDENTITY}

As the previous paragraphs have demonstrated, objects in autobiographical discourse represent epistemology's other, the things that cannot be known, the stuff that resists (narrative) sense making. In What They Saved heirlooms obtain two different roles: they are 'objects' in the sense of objectness or resistance and they are 'things' in the sense of the Old German tinc: a gathering (cf. Heidegger 1971). The heirlooms as things connect people and artifacts; the heirlooms as objects trigger questions concerning the limits of (narrative) meaning making and resist traditional epistemological mechanisms, concepts and interpretations.

Thing theorist Bill Brown particularly highlights this aloofness and alterity of things when he states that "thinking and thingness are distinct" (Brown 2001, p. 16). Archeologist Nicole Boivin argues in the same vein when she states that artefacts "do not necessarily symbolise anything else: their very power may lie in the fact that they are part of the realm of the sensual, of experience, and of emotion, rather than a world of concepts, codes, and meaning" (Boivin 2008, p. 9). It is the sensuous engagement of people with things, which points towards the very materiality of human life.

One example on how the encounter with objects eludes idealist conceptions of things as symbols can be found in Nancy's reaction towards the silver cigarette case which she finds in the drawer. The protagonist observes her grandfather on a photograph, "holding the silver object between his thumb and index finger, in the palm of his right hand." (p. 61) The strong impression of physical touch that is evoked by the detailed description of the grandfather's grasp of the case is even strengthened by a photographic reproduction of the cigarette case on the opposing page (p. 60). The episode exemplifies a sensuous engagement with an heirloom that transcends the conceptual and leads towards the impression of 


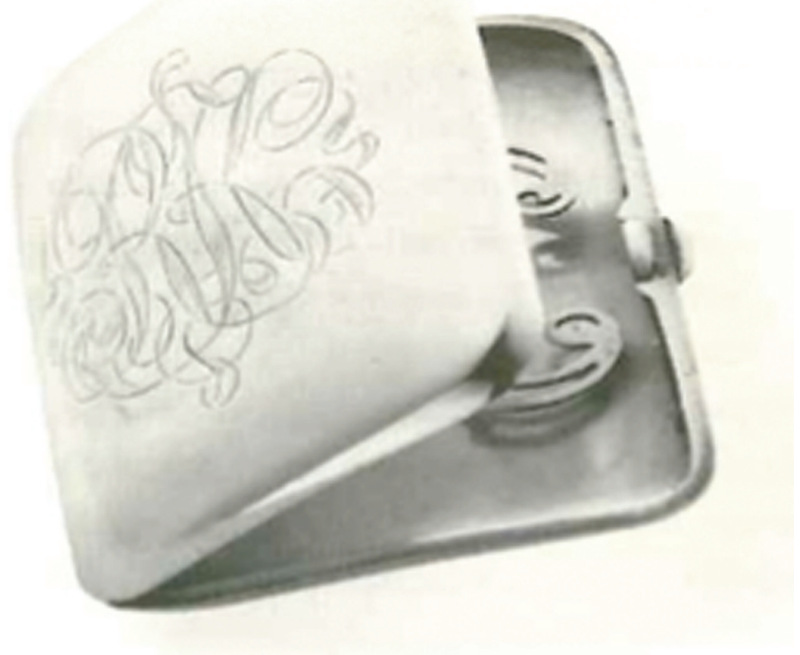

a true encounter that transcends place and time: "I can trace with my fingers the slight indentation where his thumb must have grasped the case" (p. 61). Furthermore, the evocation of touch does not only connect Nancy and her ancestors, but also includes or rather in-corporates the reader as a participant of the story because the slight indentation Nancy refers to can be seen and touched on the opposing book page.

The cigarette case points towards the potential of artefacts to refashion autobiographical identity. It makes the family biographer re-evaluate her own sense of self: "When I started smoking in the 1960s, I thought I was cool; I had no idea I was following in a family tradition" (ibid.). Eventually, the touch of the object, the physicality of the cigarette case, brings Nancy much closer to her lost family than her articulate research. The heirlooms constitute a co-presence of different owners realized on the spatial surface of the object and, thereby, create a space-based encounter that is impossible on a temporal axis. The episode exemplifies the agency of objects, which can cause an effect in the way people understand themselves and make sense of their lives.

Nevertheless, even though the haptic experience of the heirloom highlights the pure materiality of material culture that moves beyond symbolic aspects, Nancy cannot stop at the pure materiality, but uses the sensual experience to gain new metaphors from it. The metal surface 
of the cigarette case makes her perceive her attempts to reconstruct the family's past as "polishing":

Not just literally, but as a metaphor, or better, a metonymy, a figure of speech
that expresses the connection between things and that helps me gather up
and mend the fragile ties to the vanished side of the family, a story to stand
in, even make up, for all the stories that were never passed on. (pp. 60-61)

The interpretation of the objects as connectors between people, times and spaces is further highlighted by the hint that her grandfather is positioned in front of a chain-link fence on the photography that shows him with the cigarette case. Miller transforms this observation into the metaphor of "the chain of inheritance." The family biographer interprets the heirlooms as interpersonal and intergenerational interfaces which allow for the overlapping of life stories. The objects, which have been present in the past and in the authorial present, provoke a sense of simultaneity and direct the autobiographer's attention to the fact that the heirlooms are always already a palimpsest of diverse and overlapping processes of interpretation. They point towards multiple meanings and the polysemy of objects. On the one hand, they carry the meaning advised to them by the ancestors, on the other hand, they gain their meaning from the sensemaking processes of the new owners who are situated in totally different historical, geographical, social and religious contexts.

\section{BEYOND NARRATIVE: THE PRIVATE MUSEUM AS A MATERIAL-SEMIOTIC INTERFACE}

The urgency that drives the family biographer to solve the riddles represented by the objects and to reconstruct the stories behind them is not least due to the fact that Nancy has no children of her own and therefore regards herself as the last link in the chain:

$[\mathrm{G}]$ iven my place at the end of the line, there is no next generation who will inherit from me; I end up an heiress minus heirs [...] But if I'm stuck with my objects unless they become recognizable paper shapes - Jewish origami? - I've at least made that move outward to the readers who share the dilemma of uncertain origins and unrootedness, and wasn't that the point of the journey? (p. 225)

The quote highlights the tension between the autobiographer's urge to gain or construct meaning in the form of life narratives while she has simultaneously developed an awareness for the special power of objects 
that lies beyond the discursive strategies of life narrative. Although Miller writes an autobiographical text and a family biography in the end, she resists the temptation to give in to a coherent story and defies being overwhelmed by the supposedly unitary and transparent account giving the generic formulae might dictate. Rather, she highlights the dead ends of her research and the gaps of knowledge that dominate her life writing project, which she describes as "my portfolio of silenced stories and disappeared relatives" (p. 72). Her decision to translate the sensual materiality into a narrative is motivated by the strive to share both the story and the insights gained while she worked on it with others: "Little by little, I'm moving the contents of the drawer into a shareable story" (p. 121). Her behavior is motivated by the insight that she is not only the terminus of her own history but also of the family story that precedes her and that surpasses the borders of individual lives.

Apart from the translation of the artefacts into a shareable story, the autobiographer also decides to pursue an alternative way of storing and conserving her family biography and decides to install a "private museum" (p. 218), where she keeps the artefacts as objects. Nevertheless, even during the process of curating she cannot escape from the symbolic value the objects still seem to represent. Especially the tefillin she inherited from her father are conceived by Nancy as "a symbolic reminder of what binds Jews to God"; p. 216). Her considerations show that even a materialist approach towards the heirlooms does not preclude a concern with symbolic meanings. It might even be argued that Nancy's decision to display the objects as a museum has certain parallels with the idea of an ancestral shrine. It is especially through the verb "to bind" that the interface between materiality and symbolic meaning gains full force here. Worn by observant Jews during their weekday morning prayers, the tefillin and their way of application - wrapped around arm, hand, fingers and head - effect the expression used and the feeling evoked towards them. This shows that biographical objects can indeed be more than a projection of symbolic concepts but rather serve as agents, which effect the concept. The tefillin acclaim the role of non-human agents, who perform an active part in the processes of meaning making. They function as material-semiotic interfaces (cf. Haraway 1991, p. 198 ff; Latour 1993).

\section{SITUATED KNOWLEDGES AND HETEROGENEOUS HISTORY}

In What They Saved, Miller highlights the tension between the knowable and the unknown, stories that might be recovered and those, which are lost forever. The protagonist's reflections on the process of making an identity narrative highlight that neither self nor reality is a stable referent 
but rather a culturally dependent construct. Facing the unknown hinted at by the objects but irretrievably lost in terms of narration, she interchanges imagination, or what she calls "glamorous vagueness," with the "banal realities of historical factness" (p. 44): "When I find myself stuck in contradictory versions, I'm forced to ... give up on biographical truth and go in the direction of what's available" (p. 110f.). Hence, she describes the heirlooms as constituting "the map of [her] vast ignorance" (p. 41).

Writing a "family biography" (p. 150) based on an amalgam of letters and objects points to "the inevitable partiality of auto/biographical narratives" (Tamboukou 2013, p. 3). The objects reject the most typical expectation connected to autobiography: the idea of auto/biographical truth and the representation of a 'real past.' Instead, they remind us that in the context of auto/biography historical truth sometimes can only be grasped as a play with possibilities. Conceptioning the autobiographer as an archivist helps to point out that autobiographical narratives are fragmented through and through, there is always something missing. Nancy's frustration with the search for the authentic and really real culminates in the insight that original or true history doesn't exist.

Regarding the epistemological gaps resulting from the silence of the objects, the question "[W]ho saved and why?" (p. 192) can seldom be answered in a definitive way. This can be illustrated by the blonde lock of hair which Nancy finds in the French soap box. The locks of hair might be connected to the cultural or religious traditions of her Jewish ancestors: are these the temple curls of an orthodox Jew? Or did they belong to a bride who had to undergo the procedure of bridal shaving (p. 193)? Or does this artefact bear no connection to Jewish culture at all and simply represents a loved child's first hair? Maybe the hair of a child lost too early? To actualize the material object of hair as a cue which then could trigger memories, the American great-granddaughter would need a narrative to position the object in. This narrative, however, is lost forever.

Unlike a letter, hair is unsigned, and as family hair it looms large in my imagination. The locks are links in a chain that binds me tightly to the past, even if I can't fully decipher either hair or past. (p. 195)

Instead of obscuring her interpretational efforts, Miller exposes her strategies of sense making: she is not only constructing a story out of her findings, but at the same time deconstructs it. It is therefore that What They Saved makes a plea for "situated knowledges" (Haraway 1988, p. 581). Instead of stating facts, she creates conditions of possibility for meaning and knowledge to emerge and thereby demonstrates that interpretation is bound to a "situated perspective" (Tamboukou 2013, p. 11). Miller describes the heirlooms as a "representation of past lives at several 
removes" (p. 215) and thereby highlights the fact that she will never be able to find out the truth about her ancestors. All she can hope for are glimpses into their "ethnographic surround" (p. 31), the web of material conditions and discursive practices constitutive of their world. This is by no means an argument for simple relativism but rather for an "epistemology of partial perspectives" (Tamboukou 2013, p. 11) and a "practice of objectivity that priviledges contestation, deconstruction, passionate construction, webbed connections" (Haraway 1988, p. 585). The object of the unidentified lock of hair cannot achieve meaning independently from the agency and the locatedness of the researcher.

Finally, just like the tefillin discussed in the chapter before, the locks of hair are not only interpreted by the protagonist but they also excert their own actions and thus become visible as active agents in the process of meaning making. Even though the family biographer feels excluded from the family stories that would make it possible to advise meaning to the object, it is the pure matter, her own hair, which finally connects her to the lost branch of the family: " $[\mathrm{M}] \mathrm{y}$ tribal hair - the rigid mass, that in my mind at least, always marked me as a Kipnis, signaled my descend from this line through my father's hair [...]"; p. 138). By regarding the locks as "a chain that binds [her] tightly to the past" (p. 195) the protagonist forms a connection to the past that is not dependent on narrative meaning making, but on pure materiality. Though her father never included her into the intergenerational family narrative that would allow her to take part in the familial postmemory, it is the matter of her hair itself, which as an active agent, connects her to a long lost family tradition.

\section{AUTOBIOGRAPHY AND THE WEB OF ENTANGLEMENT}

Perhaps it is time to understand the question of relation to the other - to others - as being as important, foundational, to the genre as the truth conditions of the 'autobiographical pact'. Not the exception but the rule. Put another way, in autobiography the relational is not optional. Autobiography's story is about the web of entanglement in which we find ourselves, one that we sometimes choose. (Miller 2007, p. 544)

The idea of self put forward in What They Saved is deeply grounded in a relational understanding of identity as it has been conceptualized by feminist scholars in the 1980s and expanded by Susanna Egan (1999) and Paul John Eakin (1999) at the end of the $20^{\text {th }}$ century. ${ }^{4}$ As "palimpsests of joint ownership" the objects in What They Saved have shown the web of entanglement that includes different people, times and places and 
also the non-human, material world as an often underestimated element of relationality. Also, the social scientist Ruthellen Josselson argues in a similar vein when she proclaims a "relational turn in the understanding of human life":

The late $20^{\text {th }}$ century critique of the social science depiction of human beings as (desirably) autonomous, individuated, and self-reliant has given way to a view of people as interrelated, interdependent, and mutually constructive not only regarding other people, but also regarding the objects in their everyday life. (Josselson 2007, p. 5)

Both, Miller's search for her Jewish self and her investigation of the Kipnis's past emerged through multifarious entanglements, between the auto/biographer, the inherited objects and their contexts. Therefore, neither of them can be considered as a predefined entity but has been constituted through multifarious entanglements. This is why Karen Barad correctly argues that "existence is not an individual affair. Individuals do not preexist their interactions: rather individuals emerge through and as part of their entangled intra-relating" (2007, p. ix).

In What They Saved the autobiographical subject and the inherited objects acclaim meaning in a process of entanglement. As follows from this, objects in autobiography might well be said to serve the function to challenge and problematize the unity of the entities earlier considered as given originals like the self, the family history or the past. Instead, the autobiographer's self and the familial past become obvious as possible knowledges. Their meaning depends on the situatedness of the biographer.

\section{OBJECT-BASED EPISTEMOLOGY AND LIFE WRITING IN EUROPE - TEXTS TO GET ENGAGED WITH}

Although this text dealt with an American life writing text, the figure of the family archivist is also a common character in nowadays European life writing texts. The British authors Hanif Kureishi (2004) and Julian Barnes $(2008)^{5}$ show their autobiographical protagonists as suffering from the unknowability that derives from a story saved in objects: "And there it all runs out, memory and knowledge. These are the available scraps; nothing more can be known" (Barnes 2009, p. 238).

Regarding contemporary German literature ${ }^{6}$ the example of Katja Petrowskaja's Vielleicht Esther (Maybe Esther) ${ }^{7}$ shows a similar occupation with the specific epistemological challenges connected to the position of the postmemorialist. Petrovskaja was born in Kiev in 1970. She studied literature in Tartu (Estonia), obtained her PhD in Moscow and writes 
in German. She won the Ingeborg Bachmann prize in 2013 and published her first novel in March 2014. Vielleicht Esther is a family biography and tells the tale of Petrowskaja's paternal great-grandmother living in Nazi-occupied Kiev. Nevertheless, if even her name cannot be known for sure, what can we know at all?

„Ich glaube, sie hieß Esther, sagte mein Vater. Ja, vielleicht Esther. Ich hatte zwei Großmütter, und eine von ihnen hieß Esther, genau.

Wie, vielleicht!? fragte ich empört. Du weißt nicht, wie sie hieß? Ich habe sie nie bei ihrem Namen genannt, erwiderte mein Vater. Ich sagte Babuschka, und meine Eltern sagten Mutter.“ (Petrowskaja 2014, p. 209)

"I believe her name was Esther, my father said. Yes, maybe Esther. I had two grandmothers, and one of them was named Esther, I'm sure of it.

What do you mean, maybe? I asked, indignant. You don't know your own grandmother's name?

I never called her by her name, my father replied, I always said Babushka and my parents always called her Mother." (trans. by Adrian West)

Just like Nancy in Miller's text, also Petrowskaja's autobiographical protagonist travels and visits the important places of her family history to be able to contextualize the lost relatives in their lost contexts. Herself living in Berlin, Petrowskaja connects diverse settings in Poland, Ukraine, Russia, Australia and Germany and thereby explores a cross-border European space and a cross-border European past. $^{8}$ After the rest of the family left Kiew, Esther's fate can only be reconstructed through the reports of the janitor of the house that no longer exists and who told everything to Katja's grandfather Semjon. On September 29 ${ }^{\text {th }}$ in 1941 'Maybe Esther' left her apartment to comply with the instructions of the Nazis and to gather with the other remaining Jews of Kiev for a supposed resettlement. More than 30,000 Jews living in Kiev were massacred this day.

How exactly did she manage to leave her apartment, to climb the stairs - history doesn't tell. "Well, the neighbours must have helped her ..." Like other family archivists, Petrowskaja flees into the subjunctive, the tense of maybe, the mode of Maybe Esther. Still, she challenges the fragmentariness and partiality of her knowledge by positioning herself at the neighbouring house's window, decades later, imagining to see everything from above:

Ich beobachte diese Szene wie Gott aus dem Fenster des gegenüberliegenden Hauses. Vielleicht schreibt man so Romane. Oder auch Märchen. Ich sitze oben, ich sehe alles! Manchmal fasse ich mir ein Herz und komme näher heran ... So sehr ich mich bemühe, ihre Gesichter zu sehen, in ihre Gesichter zu schauen ... wie sehr ich mich auch strecke, um sie anzuschauen und alle Muskeln meines Gedächtnisses, meiner Phantasie und meiner 
Intuition anspanne - es geht nicht. Ich sehe die Gesichter nicht. Verstehe nicht, und die Historiker schweigen. (Petrowskaja 2014, p. 221)

I watch this scene like God from the window of the house across the street. Maybe this is how novels are written. Or fairy tales. I sit up there, and I see everything! Sometimes I get courageous and come up close ... I try so hard to see their faces, to look into their faces ... but no matter how much I stretch and strain all the muscles of memory, of imagination and intuition - it doesn't work. I don't see the faces, I don't understand, and the history books are silent. (trans. by Adrian West)

The quote demonstrates an attempt to circumvent one's own situatedness and the situated and partial knowledge inevitably connected to it; it is an attempt to play God. Being human, however, this is what the objects in life writing might teach us, is to be challenged to accept one's epistemologies as partial and situated.

While traditional autobiography theory relied on the concept of the knowing subject that has immediate access to its own life story, those narratives focussing on the materiality of a life draw attention to the (contextual) locatedness of the autobiographer and put forward the idea that all (self) knowledge is situated knowledge. As a consequence, objects in autobiography reveal that processes of autobiographical sense making cannot simply rely on the self's transparency to the self. Instead, they show that neither knowledge nor sense making is an individual affair. Autobiographical knowledge is not a product of the inert self, but emerges through the entangledness of the autobiographer. And this entanglement does not only include the world of concepts and ideas. Objects in autobiography resist the processes of purely mind based epistemology and ask for the knowledge of the body: the DNA, the hair and the sensual knowledge derived from touch.

\section{WORKS CITED}

Barad, Karen. Meeting the Universe Halfway: Quantum Physics and the Entanglement of Matter and Meaning. Durham, NC: Duke University Press, 2007.

Barnes, Julian. Nothing To Be Frightened Of. London: Vintage, 2009 [2008].

Boivin, Nicole. Material Cultures, Material Minds: The Impact of Things on Human Thought, Society and Evolution. Cambridge: Cambridge University Press, 2008.

Brown, Bill. "Thing Theory." Critical Inquiry 28.1 (2001): 1-22.

Eakin, Paul John. How Our Lives Become Stories: Making Selves. Ithaca/London: Cornell University Press, 1999.

Eakin, Paul John. Living Autobiographically: How We Create Identity in Narrative. Ithaca/ London: Cornell University Press, 2009.

Egan, Susanna. Mirror Talk. Genres of Crisis in Contemporary Autobiography. Chapel Hill: University of North Carolina Press, 1999. 
Fioretos, Aris. Halva Solen. Stockholm: Norstedts, 2012.

Freeman, Mark. Hindsight. The Promise and Peril of Looking Backward. Oxford: Oxford University Press, 2010.

Haraway, Donna. "Situated Knowledges: The Science Question in Feminism and the Priviledge of Partial Perspective." Feminist Studies 14.3 (Autumn 1988): 575-599.

Haraway, Donna. Simians, Cyborgs, and Women. The Reinvention of Nature. Routledge: New York, 1991.

Heidegger, Martin. "The Thing." Poetry, Language, Thought. New York: Harper Collins, 1971. 174-182.

Hirdman, Yvonne. Den röda grevinnan: en europäisk historia. Stockholm: Ordfront, 2010.

Hirsch, Marianne. Family Frames: Photography, Narrative, and Family Postmemory. Cambridge (MA): Harvard University Press, 1997.

Hodder, Ian. Entangled: An Archaeology of the Relationships between Humans and Things. Malden (MA): John Wiley \& Sons, 2012.

Hornung, Alfred. "Return Visits: The European Background of Transcultural Life Writing." The European Journal of Life Writing 2 (2013): 10-24.

Josselson, Ruthellen. "Introduction." The Meaning of Others. Narrative Studies of Relationships. Eds. Ibid., Amia Lieblich and Dan P. McAdams, 2007. 3-10.

Karpinski, Joanne. "Artefacts and Life Writing." Encyclopaedia of Life Writing: Autobiographical and Biographical Forms. Ed. Margaretta Jolly Vol 1: A-K. London/Chicago: Fitzroy Dearborn, 2001. 55-57.

Kimmich, Dorothee. Lebendige Dinge in der Moderne. Konstanz: Konstanz Univeristy Press, 2011.

Latour, Bruno. We Have Never Been Modern. Trans. by Catherine Porter. Harvard University Press, 1993.

Leo, Per. Flut und Boden: Roman einer Familie. Stuttgart: Klett-Cotta, 2014.

Leupold, Dagmar. Nach den Kriegen. Roman eines Lebens. München: Beck, 2004.

Linke, Gabriele."Belonging" in Post-Communist Europe: Strategies of Representation in Kapka Kassabova's Street without a Name." The European Journal of Life Writing 2 (2013): 25-41.

Maron, Monica. Pawels Briefe. Eine Familiengeschichte. Frankfurt/Main: Fischer, 2009.

Miller, Nancy K. Bequest $\mathcal{E}$ Betrayal: Memoirs of a Parent's Death. New York/Oxford: Oxford University Press, 1996.

Miller, Nancy K. But Enough of Me: Why We Read Other People's Lives. New York: Columbia University Press, 2002.

Miller, Nancy K. What They Saved: Pieces of a Jewish Past. Lincoln/London: University of Nebraska Press, 2011.

Petrowskaja, Katja. Vielleicht Esther. Frankfurt/Main: Suhrkamp, 2014.

Petrowskaja, Katja. Maybe Esther. Trans. by Shelley Frisch. Forthcoming from Harper Collins.

Porter, Roger J. Bureau of Missing Persons: Writing the Secret Lives of Fathers. Ithaca/New York: Cornell University Press, 2011.

Rüggemeier, Anne. Die relationale Autobiographie: Ein Beitrag zur Theorie, Poetik und Gattungsgeschichte eines neuen Genres in der englischsprachigen Erzählliteratur. Triert: WVT, 2014.

Tamboukou, Maria. "Archival Research: Unraveling Space/Time/Matter Entanglements and Fragments." Qualitative Research 2013 (online).

\section{ABOUT THE AUTHOR}

Anne Rüggemeier is Junior Research Group leader at the Heidelberg School of Education (University of Heidelberg/Heidelberg University of Education). She wrote her $\mathrm{PhD}$ thesis on relational autobiographies in 
contemporary English Literatures and published various articles on life writing and medialisation, multimodality in self narratives and autobiographers as family archivists. Her research interests include teaching multimodal literacies, illness narratives, narratology and the field of literature and knowledge.

\section{NOTES}

1 The relationship between parents and children is a recurring topic in Miller's academic and autobiographical work (cf. Miller 1996, 2002).

2 A tallis is a Jewish prayer shawl. Tefillin are a set of small black leather boxes containing scrolls of parchment inscribed with verses from the Torah. The Torah commands that they should be worn to function as a sign of remembrance that God led the children of Israel out of Egypt.

3 Also compare the articles by Alfred Hornung and Gabriele Linke in EJLW vol. II (2013).

4 Also compare Rüggemeier 2014.

5 Cf. Barnes (2009: p. 27): "I have become by default, our archivist. In a shallow drawer, a few yards from where I am writing, sits the entire corpus of documentation: the certificates of birth and marriage and death, the wills and grants of probate, the professional qualifications, references and testimonials; the passports, ration cards, identity cards (and cartes d'identitê); the scrapbooks and notebooks and keepsakes."

6 As further examples one might consider Per Leo's Flut und Boden (2014), Monica Maron's Pawels Briefe (2009) and Dagmar Leupold's Nach den Kriegen (2004). Apart from that it seems promising to also pay attention to the Swedish life writing pieces by Yvonne Hirdman (Den Röda Grevinnan, 2010) and Aris Fioretis (Halva Solen, 2012).

7 The English translation will be forthcoming from Harper Collins. I am indebted to Adrian Nathan West to provide me with his translations of the parts quoted.

8 The same is true about Fioretos, Hirdman, Maron and Leupold. 